\title{
Supervisi Pembelajaran Tahfizhul Qur'an Berbasis Grup Whatsapp di Masa Pandemi Covid-19
}

\author{
Eka Novie Budiyati \\ Universitas Islam Negeri Maulana Malik Ibrahim Malang \\ e-mail: Novieazarqi17@gmail.com
}

\begin{abstract}
The country of Indonesia at this time has been hit by a calamity in the form of COVID-19 plague. To break the chain of transmission of the spread of the virus. hence, by doing work such as online-based learning. The application used is like Via Whatsapp grup. The focus of this research is: (1) how is the implementation of tahfizhul Qur'an learning based on Whatsapp group in the pandemi COVID-19 situation, (2) what methods are used in learning tahfizhul Qur'an based on Whatsapp grup in the pandemi COVID-19 situation, and (3) how is the implementation of supervision of tahfizhul Qur'an learning based on Whatsapp group in the pandemi COVID-19 situation. The purpose of this study is: (1) To analyze the implementation of tahfizhul Qur'an learning based on Whatsapp group in the COVID-19 pandemi situation, (2) describing the methods used in learning tahfizhul Qur'an based on Whatsapp grup in a pandemi COVID-19 situation, (3) and describing the supervision of tahfizhul Qur'an learning based on Whatsapp group in the covid-pandemi situation. In this study, researchers used a qualitative descriptive approach. Data collection was used through interviews and documentation. The results of the study can be known as follows: (1) the implementation of Al-Qur'an learning takes place in private chats between teachers and students. Parents record children who are reciting or memorizing, then are sent CP to the teacher in the form of Voice notes, audio, video or photos, (2) Using the Ummi method in which memorization uses the Talaqqi method where the teacher exemplifies it repeatedly and then followed by a followed learners until memorized and fluent and tartil, (3) if where there is reading that is read by students is still felt insufficient then, the teacher immediately justifies it by providing feedback as a form of supervision in the form of voice notes or videos and provide advice or words motivation. If the readings of students are considered correct, the teacher will give words in the form of happy praise and emoticons, trophies, stars, and others.
\end{abstract}

Keywords. Learning Supervision, Whatsapp group

Abstrak. Negara Indonesia pada saat ini telah dilanda musibah berupa wabah covid-19. Untuk memutuskan mata rantai penularan penyebaran virus. maka, dengan cara melakukan pekerjaan seperti pembelajaran berbasis online. Adapun salah satu aplikasi yang digunakan ialah seperti Via Whatsapp grup. Fokus penelitian ini adalah: (1) Bagaimanakah pelaksanaan pembelajaran tahfizhul qur'an berbasis via whatsapp grup disituasi pandemi covid-19, (2) Metode apakah yang digunakan dalam pembelajaran tahfizhul qur'an berbasis via whatsapp grup disituasi pandemi covid-19, (3) Bagaimanakah pelaksanaan supervisi pembelajaran tahfizhul qur'an berbasis via whatsapp grup disituasi pandemi covid-19. Adapun tujuan penelitian ini ialah: menganalisis pelaksanaan pembelajaran tahfizhul qur'an berbasis via whatsapp grup disituasi pandemik covid-19, mendeskripsikan metode yang digunakan dalam pembelajaran tahfizhul qur'an berbasis via whatsapp grup disituasi pandemi covid-19, dan mendeskripsikan ssupervisi pembelajaran tahfizhul qur'an berbasis via whatsapp grup disituasi pandemik covid-19. Dalam halm ini peneliti menggunakan pendekatan 
deskriptif kualitatif. Pengumpulan data yang digunakan melalui wawancara dan dokumentasi. Hasil penelitian dapat di ketahui sebagai berikut: (1) pelaksanaan pembelajaran Al-Qur'an berlangsung secara chat pribadi antara guru dan peserta didik. Orang tua merekam anak yang sedang ngaji atau menghafal, kemudian dikirim secara CP ke-guru baik berupa Voice note, audio, vidio maupun foto, (2) Menggunakan metode Ummi yang didalam penghafalannya menggunakan metode Talaqqi yaitu guru mencontohkan secara berulang-ulang kemudian diikuti oleh peserta didik sampai hafal dan lancar serta tartil, (3) jika mana terdapat bacaan yang dibaca oleh peserta didik masih dirasa kurang mantap maka, guru langsung membenarkannya dengan cara memberikan feedback sebagai bentuk pengawasan berupa Voice note atau video dan memberikan nasehat maupun kata-kata motivasi. Apabila bacaan peserta didik dirasa benar maka, guru akan memberikan kata-kata berupa pujian dan emoticon gembira, piala, bintang dan lainnya.

Kata Kunci. Supervisi Pembelajaran, Grup Whatsapp

Copyright (c) JMPI: Jurnal Manajemen Pendidikan Islam. All Right Reserved.

This is an open access article under the CC BY-NC-ND license

(http://creativecommons.org/licenses/by-nc-nd/4.0/).

\section{A. PENDAHULUAN}

Setiap kehidupan, roda waktu semakin berputar seiring dengan berkembangnya zaman yang terus-menerus hingga menjadi modern seperti keadaan pada saat ini. Hal tersebut dapat dilihat melalui berkembangnya segi teknologi, ekonomi, sosial, dan pendidikan. Dalam situasi saat ini, keempat hal tersebut seperti teknologi, ekonomi, sosial, dan pendidikan akan saling berlomba-lomba dalam mengembangkan ruang lingkupnya. Dimana orang-orang akan berlomba meraih ilmu pengetahuan sehingga nantinya apa yang menjadi keterampilannya bisa ia kembangkan untuk memajukan salah satu dari ke empat segi tersebut.

Ilmu pengetahuan, keterampilan, serta sikap. Semuanya tidak lepas dari yang namanya pendidikan dan pembelajaran. Disini pendidikan akan membantu orang dalam menerima pembelajaran mengenai ilmu pengetahuan, keterampilan, serta kebiasaan orang yang dimiliki untuk diajarkan kegenerasi setelahnya. Pendidikan sering terjadi dengan arahan dan bimbingan dari orang lain namun, juga dapat dengan belajar secara mandiri atau dapat kita sebut dengan ssebutan otodidak. (John Dewey, 1944:1-4). Seperti yang diungkapkan oleh Harahap dan Poerkatika bahwasannya pendidikan merupakan upaya yang dilakukan dengan sengaja oleh orang tua yang mana selalu mengartikan bahwa pendidikan dapat dikaitakan dengan memunculkan sebuah perilaku bertanggung jawab moral. (Syah Muhibbin, 2007: 11). Adapun orang tua yang dimaksud disini ialah orang yang memiliki kewajiban dalam membimbing atau mendidik seperti kyai, pendeta dan orang tua. Adapun pembelajara merupakan aktivitas yang kpmplek. Yang pada hakikatnya bukanlah sekedar menyampaikan informasi akan tetapi merupakan sebagin kegiatan yang bersifat professional yang mengharuskan pendidik untuk bisa menggunakan kemampuannya seperti seni keterampilan dasar dalam mengajar dan menjadikan kondisi ke dalam bentuk yang tepat (Mashudi, Toha dkk, 2007: 3). Maka dari itu, pembelajaran merupakan bagian yang utama dan penting untuk mencerdaskan bangsa untuk mencapai tujuan SDM Negara yang berkualitas sehingga dapat menjadikan Negara dapat maju untuk bersaing dengan Negara lainnya. Hal ini tidak lepas dari bimbingan, arahan, 
pendidikan dari para pendidik yang mana membantu dalam berjalannya proses pembelajaran.

Dalam pembelajaran tidak akan selalu berada di posisi yang selalu maju akan tetapi juga dapat mengalami kemunduran sewaktu-waktu tanpa diketahui. Tentu saja hal ini berdampak bagi Negara Indonesia, lembaga pendidikan sekolah, serta dirinya sendiri yang menjalani proses pembelajaran ini. Untuk dapat mencegah hal yang tidak diinginkan maka, diadakanlah supervisi pembelajaran untuk dapat memperbaiki kesalahan yang telah diperbuat menuju yang jauh lebih baik, bentuk dari memberikan membantu agar kompetensi belajar peserta didik semakin baik, dan menjadikan proses pembelajaran yang semakin efektif dengan pemantauan yang baik dari para pendidik.

Supervisi sendiri diartikan sebagai bantuan jasa dalam membimbing, menyediakan fasilitas, memberikan motivasi dan mengoreksi pendidik dalam menyelenggarakan pembelajaran, serta membantu dalam menumbuhkembangkan profesi agar efektif. Sedangkan supervisi pembelajaran diartikan sebagai "memberikan bantuan berupa jasa yang telah disiapkan oleh pemimpin untuk menuju perbaikan dengan cara memberikan bantuan kepada para pendidik dengan tujuan membentuk personal semakin cakap tepat pada perkembangan ilmu pendidikan dan menjadikan proses belajar mengalami peningkatan (Nawawi, 1981: 104). Supervisi pembelajaran dalam hal lain dapat juga di artikan sebagai Upaya memajukan, mengatur, mendorong, serta mengarahkan pertumbuhan pendidik secara terus menerus di lembaga sekolah baik perorangan atau kelompok agar lebih efektif dalam menjalankan fungsi pembelajaran (Sergiovanni, 1988).

Melihat Negara Indonesia yang mana pada saat ini telah dilanda musibah berupa wabah covid-19 yang mana semakin membuat banyaknya korban yang berjatuhan sehingga mengharuskan kita untuk memutuskan mata rantai penularan penyebaran virus dengan cara berdiam diri dirumah serta melakukan pekerjaan seperti pembelajaran berbasis online yang mengandalkan system teknologi. Adapun salah satu aplikasi yang digunakan ialah seperti Via Whatsapp grup untuk memenuhi kebutuhan dalam menjalankan proses belajar mengajar.

Aplikasi via whatsapp grup dilihat dari laman Google Play Store untuk aplikasi whatsapp merupakan sebuah aplikasi yang dinyatakan gratis dengan tujuan untuk mengimkan pesan yang telah tersedia di dalam handphone android. Aplikasi ini bisa digunakan jika menggunakannya melalui jaringan internet telephone yang tersambung ke dalam jaringan signal 4G, 3G, EDGE, atau Wi-Fi untuk menjadikan sang pengguna bisa mengirimkan dan menerima pesan, panggilan telephone, foto, video, document, serta (vn) voice note. Menurut Rohmadi (2016) bahwasannya di dalam aplikasi whatsapp terdapat indicator yang terbagi menjadi 6 bagian antara lain: Grup whatsapp diperuntukkan untu reuni, grup whatsapp untuk ruang berdiskusi, mengirim undangan sebuah acara, menelepon, berbagi lokasi google maps, dan whatsapp web untuk disambungkan ke leptop. Adapun indicator dari pemakaian whatsapp yang dijadikan media untuk digunakan dalam pembelajaran atau penelitian adalah grup whatsapp untuk berdiskusi. Hal ini memungkinkan terjadi diskusi dalam grup antara mahasiswa dengan dosen atau pendidik dengan peserta didik.

Dalam hal ini peneliti mencoba menggunakan pembelajaran tahfizhul qur'an berbasis via whatsapp grup. Pembelajaran tahfizhul qur'an sendiri merupakan system pembelajaran dengan cara menghafal, mempelajari arti atau terjemahan dengan media 
kitab Al-Qur'an. Melihat realita yang terjadi saat ini yang mana telah dijelaskan diatas maka, peneliti ingin meneliti supervisi pembelajaran tahfizhul qur'an berbasis whatsapp grup di situasi pandemik covid-19 di SDTQ An-Najah Kalimantan-selatan

Dengan berbagai masalah yang telah dirumuskan seperti: bagaimanakah pelaksanaan pembelajaran tahfizhul qur'an berbasis via whatsapp grup di situasi pandemi covid-19 di SDTQ An-Najah Kalimantan-selatan, metode apakah yang digunakan dalam pembelajaran tahfizhul qur'an berbasis via whatsapp grup disituasi pandemi covid-19 di SDTQ An-Najah Kalimantan-selatan, dan bagaimanakah pelaksanaan supervisi pembelajaran tahfizhul qur'an berbasis via whatsapp grup disituasi pandemi covid-19 di SDTQ An-Najah Kalimantan-selatan.

Adapun tujuan penelitian ini ialah: menganalisis pelaksanaan pembelajaran tahfizhul qur'an berbasis via whatsapp grup disituasi pandemik covid-19 di SDTQ AnNajah Kalimantan-selatan, menjelaskan metode yang dapat digunakan pada pembelajaran tahfizhul qur'an berbasis via whatsapp grup di situasi pandemi covid-19 di SDTQ An-Najah Kalimantan-selatan, dan mendeskripsikan supervisi pembelajaran tahfizhul qur'an berbasis via whatsapp grup disituasi pandemik covid-19 di SDTQ AnNajah Kalimantan-selatan.

Sedangkan manfaat dari penelitian ini ialah: untuk mengetahui pelaksanaan pembelajaran tahfizhul qur'an berbasis via whatsapp grup disituasi pandemi covid-19 di SDTQ An-Najah Kalimantan-selatan, untuk mengetahui metode apa yang dipakai di pembelajaran tahfizhul qur'an berbasis via whatsapp grup disituasi pandemi covid-19 di SDTQ An-Najah Kalimantan-selatan, dan untuk mendeskripsikan pelaksanaan supervisi pembelajaran tahfizhul qur'an berbasis via whatsapp grup disituasi pandemik covid-19 di SDTQ An-Najah Kalimantan-selatan.

\section{B. METODE}

Dalam hal ini peneliti menggunakan sebuah metode yang disebut dengan penelitian deskriptif kualitatif. Peneliti menggunakan metode ini dikarenakan ingin menggambarkan suatu fenomena nyata melalui pembelajaran Via Whatshapp Group yang ditujukan dalam materi tahfizhul qur'an. Kualitatif ialah metode yang digunakan dalam penelitian dengan tujuan meneliti terhadap suatu hal yang memberikan perhatian kepada peneliti yang bersifat alami, yang mana peneliti sebagai instrument kuncinya (Sugiyono, 2005). Adapun menurut Moleong (2005:6), penelitian merupakan kejadian yang menggambarkan tentang apa yang dirasakan oleh pelaku penelitian seperti: sikap, perasaan, perbuatan, arahan dan lainnya dengan holistic, serta dengan menggambarkan ke sebuah bentuk kata terhadap sebuah kedudukan yang bersifat khusus yang didasarkan oleh sifat alami dan dengan menggunakan macam metode alamiah. Adapun teknik yang dilakukan untuk pengumpulan data dilaksanakan dengan wawancara dan dokumentasi. Pelaksaan wawancara dilaksanakan terhadap para guru tahfizhul Qur'an di SDTQ An-Najah Cindai Alus martapura Kalimantanselatan secara online dengan menggunakan via whatsapp.seperti yang diungkapkan oleh sugiono (2006: 138-140) bahwasannya wawancara dapat dilaksanakan secara terstruktur atau tidak dengan secara langsung berhadapan atau menggunakan via telepon. Dokumentasi dilakukan dengan menyertakan foto proses pembelajaran tahfizhul Qur'an melalui via whatsapp group antara pendidik dengan peserta didiknya. Dokumentasi ialah kiat yang dilakukan dalam mendapatkan informasi yang kita sebut data dalam bentuk dokumen, gambar atau foto, teks atau naskah-naskah dan 
keterangan yang bisa membantu penelitian (Sugiyono, 2015: 329). Penelitian ini dilakukan di SDTQ An-Najah Kalimantan-selatan pada tanggal 10 mei 2020 hari minggu secara online dengan menggunakan aplikasi via whatsapp.

\section{HASIL DAN PEMBAHASAN}

\section{Pelaksanaan Pembelajaran Tahfizhul Qur'an Berbasis Via Whatsapp Group.}

Selama pandemi Covid-19 pembelajaran Al-Qur'an tetap berjalan seperti biasa hanya saja sistem dan waktunya berbeda. Seperti pembelajaran Al-Qur'an yang diselenggarakan di SDTQ An-Najah Kalimantan-selatan yang mana melaksanakan proses pembelajarannya secara online melalui aplikasi whatsapp. Guru membuat whatsapp group untuk laporan/pengabsenan peserta didik ketika sudah setor hafalan dan ngaji.

Selain itu juga didalam group tersebut diberitahukan sistem cara dalam setoran hafalan dan batas waktu pngumpulan hafalan melalui rekaman suara dan bukti berupa foto setiap hri ketika murojaah atau penambhan ayat. Whatsapp group juga tempat berbagi info tentang pembelajaran Al-Qur'an tempat berbagi foto/video berupa katakata yang dapat menjadikan semangat kita bertambah dalam menghafal dan mempelajari Al-Qur'an. Adapun pelaksanaan dalam memahami dan mempelajari AlQur'an berlangsung dengan chat pribadi antara pendidik dan murid. Wali dari para murid merekam anaknya yang sedang ngaji atau menghafal, kemudian dikirim secara $\mathrm{CP}$ ke-guru baik berupa Voice note, audio, vidio maupun foto (Hafizhatun Nadiya: 2020).

Gambar C.1: Salah satu Grup Tahfizhul Qur'an SDTQ An-Najah

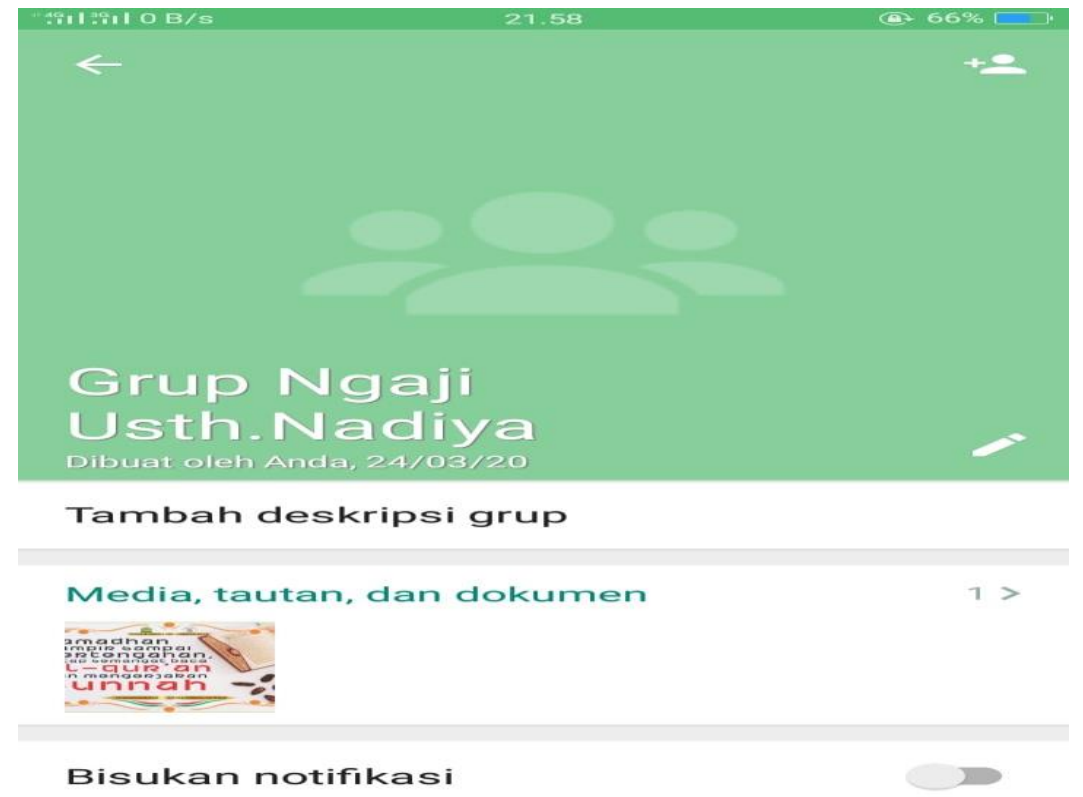

Sumber: Ustadzah Nadiya 
Seperti yang telah didefinisikan oleh Andika Prajana (2017) bahwasannya aplikasi yang tercantum di handphone seperti whatsapp yang terdapat didalamnya beberapa macam fitur untuk berkomunikasi dengan sesama pengguna. Maka dapat diketahui aplikasi whatsapp sebagai bentuk dari media untuk berkomunikasi atau berinteraksi dengan sesame pengguna melalui, handphone, web yang dioprasikan melalui computer atau sejenis laptop. Hal lain juga senada dengan apa yang diungkapkan oleh Suhu (2014) bahwa aplikasi whatsapp ialah aplikasi dari media ponsel yang menjadikan para pengguna aplikasi whatsapp dapat bertukar atau saling mengirim maps atau lokasi, pesan atau teks, video, audio atau voice note, dan gambar.

\section{Metode Pembelajaran Tahfizhul Qur'an Berbasis Via Whatsapp Group.}

Dalam mempelajari kitab Al-Qur'an di SDTQ An-Najah Kalimantan-selatan ialah menggunakan metode UMMI. Dapat diartikan yang mana merupakan salah satu metode yang terkandung dalam pembelajaran Al Quran. Yang mana didalam penghafalannya menggunakan metode Talaqqi yaitu guru mencontohkan secara berulang-ulang kemudian diikuti oleh peserta didik sampai hafal dan lancar serta tartil. Adapun mengapa metode ini digunakan ialah karena metode Ummi bermakna seorang ibu yang memiliki saifat-sifat seperti lemah lembut, penyabar, dan tawakal.

Terdapat tiga motto dalam menggunakan metode ini sebagai berikut:

1. Mudah, dirangkai dengan tujuan memberikan kemudahan untuk digunakan dan dipahami oleh peserta didik, ringan untuk dipakai dalam menyalurkan materi yang diintegrasikan kepada pembelajaran disekolah.

2. Menyenangkan, dilakukan dengan suatu proses pembelajaran yang bersifat atraktif dan ceria yang kemudian akan menjauhkan pemikiran rasa ketakutan mereka saat mempelajarai Al-Qur'an.

3. Menyentuh hati, dalam metode Ummi tidak hanya pemberian materi Al-Qur'an bersifat material terdidik saja, namun juga memberitahukan sebuah akidah AlQur'an yang dipraktekkan kedalam [erilaku-perilaku ketika proses pembelajaran terjadi.

Untuk itu pembelajar harus menguasai bacaan-bacaan panjang, yang meliputi (mad thobi'i, mad aridli Sukun, dan bacaan panjang yang lainnya), sifat-sifat huruf, cara berhentinya bacaan, dan pelafalan 28 huruf hijaiyah dengan mudah dan benar, tanda baca harkat fathah (a), kasrah (i), dhammah (u), tanwin, sukun, tasydid, dan sebagainya.

Gambar C.2: Jilid Ummi

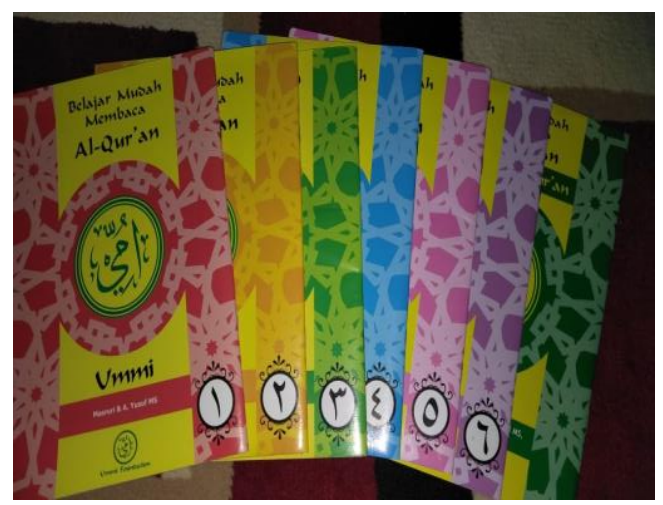


Seperti yang diungkapkan oleh Masruri dan Yusuf (2011: 4) metode ummi ialah metode dengan cara praktis agar dapat belajar mengeja bacaan sehingga dapat membaca isi yang terkandung di dalam Al-Qur'an dengan betul dan bagus. Mengenai pendasaran dalam metode ummi ialah direct method artinya "metode langsung dan tidak banyak dalam penyampaiannya", repeatition (berulang-ulang), dan kasih sayang dengan iklhlas atau mukhlis "ummi foundation". Selain itu metode ini juga diartikan metode yang membelajarkan peserta didiknya dengan tujuan untuk meningkatkan kemampuan dalam membaca Al-Qur'an dengan menggunakan pendekatan ibu yang arti bahasa arab dari Ummi tadi. Hal ini mengakibatkan anak untuk bisa berupaya menghormati dan mengingat jasa yang telah diberikan oleh ibu dalam mengajarkan bahasa kepada kita.

Hal ini juga diperkuat oleh Tim Ummi Foundation (2010: 17) bahwa penerapan Dalam belajar membaca Al-Qur'an yang menggunakan metode ummi bisa menciptakan motivasi belajar anak meningkat, kemampuan belajar Al-Qur'an secara tartil juga meningkat, serta menghasilkan bacaan yang baik dan benar. Dengan begitu dapat memberikan peningkatan untuk minat tinggi ketika sendang membaca kitab AlQur'an pada setiap diri pesrta didik. Karena metode ini dianggap kiat-kiat yang ringan dan menggembirakan untuk anak-anak. Selain itu, menurut Yusuf (2011: 4) dalm belajar Al-Qur'an menggunakan metode ummi pada hakekatnya ialah untuk memberikan suatu pembelajaran kepada anak dalam artian proses pengenalan terhadap Al-Qur'an dengan tahapan meliputi:

1. Agar siswa dapat mengetahui tanda bacaan suara atau bunyi.

2. Pengajaran membaca Al-Qurean tidak bisa disamakan seperti pengajaran yang mengandalkan membaca atau menulis yang terdapat dilembaga pendidikan SD, karena dalam pengajaran Al-Qur'an para peserta didik tidak mengerti akan makna dari huruf dan kata yang terdapat didalamnya yang tidak dipahami sehingga menjadikan hal ini bersifat urgent yaitu anak-anak diharuskan mengetahui dan mempelajari akan seni keterampilan dalam membaca Al-Qur'an yang tepat pada prosedur dan ajaran yang telah tersusun dalam ilmu tajwid. 
Adapun metode ummi ini juga sebuah metode pengajaran yang digunakan para pendidik untuk memberikan pembelajaran terhadap pendidik mengenai Al-Qur'an melalui streategi yang mudah, menyenangkan, dan menyentuh hati dalam pembelajarannya.disini metode ummi mempunyai beberapa visi yang menjadi suatu lembaga yang memiliki barisan depan dalam menciptakan generasi Qur'ani dan misinya menjadikan lembaga yang bersifat professional dalam proses belajar mengajarnya yang berkonteks pada sosial dan dakwah, menjadikan sisitem manajamennya berbasis kepada kualitas mutu serta menciptakan inti pengembangan pembelajaran Al-Qur'an.

\section{Supervisi Pembelajaran Tahfizhul Qur'an Berbasis Via Whatsapp Group.}

Pelaksanaan supervisi pembelajaran Al-Qur'an dengan menggunakan aplikasi whatsapp di SDTQ An-Najah kalimantan-selatan ialah jika mana terdapat bacaan yang dibaca oleh peserta didik masih dirasa kurang mantap maka, guru langsung membenarkannya dengan cara memberikan feedback sebagai bentuk pengawasan berupa Voice note atau video dan memberikan nasehat maupun kata-kata motivasi. Apabila bacaan peserta didik dirasa benar dan fashih maka, guru akan memberikan kata-kata berupa pujian dan emoticon gembira, piala, bintang dan lainnya.Pemberian reward semacam ini berdampak pada motivasi belajar siswa usia sekolah dasar (Anggraini et al., 2019).

Adapun hal lain dalam pelaksanaan supervisi pembelajaran tahfizh berbasis via whatsapp group "setelah masing-masing" anak mengirimkan video tugas hafalan yg di berikan guru, maka, guru akan menyimaknya yang kemudian memberikan feedback berupa perbaikan bacaan yang perlu di perbaiki bisa dengan tulisan, voice note ataupun dengan video serta mengirimkan gambar yg terdapat kalimat mengenai AlQur'an di group. Jika perlu perbaikn bacaan dan harus d contohkan maka guru mengirimkan voice note ataupun video. Tapi kalau tdk perlu contoh bacaan cukup menggunakan tulisan."

Hal ini senada dengan pengalaman dari Gerakan One Juz yang digerakkan oleh bhayu Subrata dan Pratama Widodo pada tahun 2007 lalu mengenai pengkhtaman Alqur'an ialah suatu kewajiban. Dengan menggunakan SMS atau Short Messages Service dan aplikasi Facebook, maka mereka menyebarkan program ini kesemua pelosok Indonesia. Program dalam hal ini kemudian dikembangkan dengan aplikasi whatsaap yang dikenalkan oleh kelompok lulusan mahasiswa di Surabaya bulan September 2010. Yng mana didalamnya terdapat 30 anggota yang kemudian mereka membuat grup dengan tujuan bisa saling berinteraksi dan berkomunikasi untuk khatamkan Al-Qur'an.

Adapun dalam pengkoordiniran kegiatan tersebut agar dapat menjadikan kemampuan para anggotanya bermutu dan berkemampuan maka dibentuklah beberapa tugas yang terdapat di dalamnya penanggung jawab (PJ) harian yang bergantian bertugas untuk melaporkan laporan juz, mengawasi atau memonitoring serta memanage yang ditujukan untuk pencapaian target (Republika: 2015).

\section{KESIMPULAN}

Dapat ditarik kesimpulan yang mana telah dihasilkan oleh peneliti dalam penjelasan diatas sebagai beriku: Selama pandemi Covid-19 pembelajaran Al-Qur'an tetap berjalan seperti biasa hanya saja sistem dan waktunya berbeda. Seperti pembelajaran Al-Qur'an yang diselenggarakan di SDTQ An-Najah Kalimantan-selatan yang mana melaksanakan proses pembelajarannya secara online melalui aplikasi 
whatsapp. Guru membuat whatsapp group untuk laporan/pengabsenan peserta didik ketika sudah setor hafalan dan ngaji. Selain itu di dalam grup tersebut diberitahukan sistem cara setoran hafalan dan batas waktu pngumpulan hafalan melalui rekaman suara dan bukti berupa foto setiap hri ketika murojaah atau penambhan ayat. Whatsapp group juga tempat berbagi info tentang pembelajaran Al-Qur'an tempat berbagi foto/video yang dapat menjadikan semangat mereka bertambah untuk menghafal dan mempelajari Al-Qur'an. Adapun pelaksanaan untu mempelajari AlQur'an berlangsung melalui chat pribadi antara pendidik dan anak. Para wali dari anak tersebut merekam anak yang sedang ngaji atau menghafal, kemudian dikirim secara $\mathrm{CP}$ ke-guru baik berupa Voice note, audio, vidio maupun foto.

Dalam pembelajaran Al-Qur'an di SDTQ An-Najah Kalimantan-selatan ialah menggunakan metode UMMI. Yang memiliki artian ialah sebagian sub metode yang terkandung dalam mempelajari Al Quran. Yang mana didalam penghafalannya menggunakan metode Talaqqi yaitu guru mencontohkan secara berulang-ulang kemudian diikuti oleh peserta didik sampai hafal dan lancar serta tartil. Adapun mengapa metode ini digunakan ialah karena metode Ummi bermakna ibu yang memiliki arti tidak jauh seseorang yang membesarkan kita dengan memiliki beberapa ciri sifat seperti penyabar, tawakal, dan lemah lembut.

Pelaksanaan supervisi pembelajaran Al-Qur'an menggunakan aplikasi whatsapp di SDTQ An-Najah kalimanta-selatan ialah jika mana terdapat bacaan yang dibaca oleh peserta didik masih dirasa kurang mantap maka, guru langsung membenarkannya dengan cara memberikan fedd back sebagai bentuk pengawasan berupa Voice note atau video dan memberikan nasehat maupun kata-kata motivasi. Apabila bacaan peserta didik dirasa benar dan fashih maka, guru akan memberikan kata-kata berupa pujian dan emoticon gembira, piala, bintang dan lainnya. Adapun hal lain dalam pelaksanaan supervisi pembelajaran tahfizh berbasis via whatsapp group "setelah masing-masing" anak mengirimkan video tugas hafalan yg di berikan guru, maka, guru akan menyimaknya yang kemudian memberikan feedback berupa perbaikan bacaan yang perlu di perbaiki bisa dengan tulisan, voice note ataupun dengan video serta mengirimkan gambar yg terdapat kalimat mengenai Al-Qur'an di group. Jika perlu perbaikn bacaan dan harus d contohkan maka guru mengirimkan voice note ataupun video. Tapi kalau tdk perlu contoh bacaan cukup menggunakan tulisan.

\section{REFERENSI}

Allen, Michael. (2013). Michael Allen's Guide to E-Learning. (Canada: John Wiley \& Sons).

Anggraini, S., Siswanto, J., dan Sukamto. (2019). Analisis Dampak Pemberian Reward and Punishment Bagi Siswa SD Negeri Kaliwiru Semarang. Mimbar PGSD Undiksha, Vol 7 No 3. 221-229

Dewey, John. (1916/1944). Democracy and Education. The Free Press.

Nawawi, Hadari. (1981). Administrasi Pendidikan. Jakarta: PT Gunung Agung.

Moleong, Lexy J. (2005). Metodologi Penelitian Kualitatif. Bandung: Remaja Rosdakarya.

Muhibbin, Syah. (2007). Psikologi Pendidikan Dengan Pendekatan Baru. Bandung: PT Remaja Rosdakarya.

Prajana, Andika. (2017). Pemanfaatan Aplikasi Whatsapp Dalam Media Pembelajaran 
di UIN Ar-Raniry Banda Aceh.

Rohmadi, Arif. (2016). Tips Produktif Bersosial Media. Jakarta: Gramedia.

Sugiyono. (2006). Metode Penelitian Kuantitatif, Kualitatif dan R\&D. Bandung: Afabeta.

Sugiono. (2015). Metode Penelitian Kombinasi (Mix Method). Bandung: Alfabeta.

Sugiono. (2015). Memahami Penelitian Kualitatif. Bandung: CV Alfabeta.

Suhu, S. (2014). An Analysis of Whatsapp Forensics in Android Smartphone. International Journal of Engineering Research.

Sergiovanni, T.J. dan R.J. Starrat. 1979. Supervision: Human Prespective. New York: Mc Graw-Hill Book Company.

Tim Penyusun. (2011). Sertifikasi Guru Al-Qur'an Metode Ummi. Surabaya: Ummi Foundation.

Mashudi, Toha dkk. (2007). Pembelajaran di SD. Diakses dari laman web pada tanggal 11 Mei 2020

dari: http:/ / masguruonline.wordpress.com/2013/05/20/karakteristik umum pembelajaran di sekolah dasar/ 